2016 - Volume: 17 Number: 5

Page: 963 - 973

DOI : $10.18038 /$ aubtda. 279863

Received: 27 July 2016 Revised: 06 December 2016 Accepted: 14 December 2016

\title{
BIOREMEDIATION OF ARSENIC (AS) FROM MINE EFFLUENT BY A HORIZONTAL FLOW CONSTRUCTED WETLAND: A CASE STUDY IN LARGEST BORAX RESERVE AREA IN OVER THE WORLD, KIRKA/ESKISSEHIR
}

\author{
Onur Can TÜRKER * \\ Faculty of Science and Letters, Department of Biology, Aksaray University, Aksaray, TURKEY
}

\begin{abstract}
In the present experiment, a horizontal flow constructed wetland (HFCW) planted with Typha angustifolia, was tested to bioremediation potential for arsenic from mine effluent at the field in largest borax reserve area over the world, Kurka (Eskişehir). Briefly, the objective of the present experiment was to investigate arsenic bioremediation capability of wetland system and asses the phytoremediation efficiency of $T$. angustifolia, selected as a donor plant in this study, with different initial arsenic concentrations. The results indicated that HFCW has capability to decreased arsenic in mine effluent from 49 $\mu \mathrm{g} \mathrm{L}^{-1}$ to $21.8 \mu \mathrm{g} \mathrm{L}^{-1}$ in a period of 84 days, suggesting that HFCW can defined as a reasonable low-cost treatment tool to prevent arsenic pollution. Furthermore, arsenic level in outflow samples of HFCW was stably below $10 \mu \mathrm{g} \mathrm{L}^{-1}$ (drinking water safety limit) with an inflow range from 42.3 to 42.1 arsenic $\mu \mathrm{g} \mathrm{L}^{-1}$ during the first 28 days. The results also indicated that belowground parts of T.angustifolia accumulate more arsenic from mine effluent compared to aboveground parts during experiment period. Therefore, the results suggested that belowground parts of the plant in HFCW play an important role for arsenic bioremediation from mine effluent which origin of Kırka Borax reserve area. In this respect, bioconcentration factor (BCF) for the plant which grown in HFCW was found higher than those of control group. Moreover, results of the present experiment also concluded that relatively high level of arsenic retained in the filtration media of HFCW during experiment period, indicating that filtration media which was used in HFCW can remediate arsenic from mine effluent. Consequently, the scientific insight of the present experiment can defined as present an innovative, cost effective, and easy operating method for arsenic remediation from mine effluent.
\end{abstract}

Keywords Arsenic removal, Constructed wetlands, Bioremediation, Mine effluent, Typha angustifolia

\section{INTRODUCTION}

The main environmental problem related to arsenic toxicity is to unlike organic based pollutant it is non biodegradable, retain in both terrestrial and aquatic environment, and again bioaccumulate in various ecological components especially in living organisms $[1,2,3]$. The principle sources of arsenic in environment are either geological or anthropogenic activities [2]. The anthropogenic activities such as mining operation, agrochemical application, and burning of fossil fuels are the main reason in elevated arsenic concentrations in natural environment [3]. Specifically, arsenic-rich effluents which produced with mining operation are the most important sources associated with arsenic toxicity in ecological components [4]. Therefore, the presence of arsenic in uncontrolled effluents even at relatively low-level concentrations can be harmful for terrestrial and aquatic ecosystems, especially in semi-arid and arid regions where surface water or effluents are used as drinking water source or irrigation purposes [5]. Consequently, the importance of removing or remediating the presence of arsenic from water sources can gain increasing interest in the semi-arid and arid regions, resulting in the development of several methods.

Seventy percent of total boron reserve in all over the world located in Turkey, so Turkey is one of the leading country in terms of the boron mine reserves and mining activities [5, 6]. The fact that boron is the important commercial substance within industrial activities today and requires the realization of mining operation where they have some limitation of alternative sites in the world [6]. In this respect, 
boron mining operation in Turkey is operated under Eti holding company in Eskişehir-Kırka, Kütahya-Emet, Bursa-Bigadiç, and Balıkesir-Kestelek. The mine effluent contain arsenic is produced when excessive clay materials removing from the mine ores through the water in these mine reserve area $[5,6,7]$.

Different conventional treatment technologies including ion exchange, membranes processes, and coagulation-electrocoagulation methods have been applied for the removal of arsenic from various types wastewater [4]. However, these techniques have some disadvantages such as production of secondary waste during the analysis and using chemicals [3,4]. Accordingly, an innovative, cost effective, and less complex method to remove arsenic from the wastewater is clearly imperative. Constructed wetlands (CWs) treatment technologies are defined as "green" methods that have used for wastewater treatment and they have considerable treatment performance in order to remove contaminants such as arsenic [8,9]. However, arsenic removal from various effluents through CWs is poorly understood so far, and there is no direct research associated with arsenic removal from a mine effluent which is origin of boron mine activities. Moreover, the novelty of the present experiment is to fill the gaps in application of sustainable management strategy associated with uncontrolled mine effluent and meet the needs of the pilot scale researches.

As mentioned above, the purpose of the current experiment was to investigate the performance of a wetland treatment system (HFCW) for the removal of arsenic from boron mine effluent. The specific aims of the present study were to (i) evaluated and design a pilot-scale HFCW to determine bioremediation of arsenic in boron mine effluent, and (2) asses the phytoremediation efficiency of Typha angustifolia, selected as a donor plant in this study, with different initial arsenic concentrations.

\section{MATERIALS AND METHODS}

\subsection{Research Site}

All of the experiment application was carried out in the Kurka Borax Reserve Area (39 $17^{\prime} \mathrm{N}, 30^{\circ} 30^{\prime}$ E). This reserve site is defined as the largest borax and boron producers in the world [7]. In the course of the mining and extraction application in the reserve area, large amounts of mine effluent origin waste contains arsenic and clayey materials $[5,6]$. Waters using to remove contaminants including mainly this clayey material from the borax ore is the main interest of this study.

Climate of the research site is semi-arid Mediterranean, changing generally in mean summer temperature and annual precipitation totals. Minimum temperature is above $8{ }^{\circ} \mathrm{C}$ and mean temperature is about $16{ }^{\circ} \mathrm{C}$. Furthermore, vegetation period continues from April to October in the region [10].

\subsection{Design of Wetland System and Cultivation Period}

A wetland treatment system which has horizontal flow constructed wetland (HFCW) design parameter was designed and fabricated using polyester chambers with $200 \mathrm{~cm}$ length, $100 \mathrm{~cm}$ width, and $60 \mathrm{~cm}$ in depth. The HFCW was operated according to subsurface flow design parameter based on a flow regime which kept the water level about $5 \mathrm{~cm}$ below the filtration materials. $10 \mathrm{~cm}$ high sand layer filled with at the bottom of the system. On this layer, $40 \mathrm{~cm}$ high organic based peat and sand mixture was added. Finally, $5 \mathrm{~cm}$ high gravel layer was placed and inlet/outlet sections were filled coarse gravel particle size with Ø 5-8 cm. Typha angustifolia, a popular wetland macrophyte using phytoremediation of arsenic in CWs, was used as donor species in this study [10]. Rhizomes of T.angustifolia were supplied in a wetland habitat located in Eskişehir, Turkey (39 $\left.17^{\prime} \mathrm{N}, 30^{\circ} 30^{\prime} \mathrm{E}\right)$, and T.angustifolia rhizomes were transplanted in HFCW at a plant density of about 12 rhizomes $/ \mathrm{m}^{2}$. 
In this present experiment, a control group with four rhizomes of T.angustifolia which grown in the same conditions but no arsenic addition was prepared.

Before the study start up, secondary treated wastewater was given into HFCW for support $T$. angustifolia's growth and establishes microorganisms for 90 days. Detailed information associated with system demonstration and configureuration is given Figure 1.

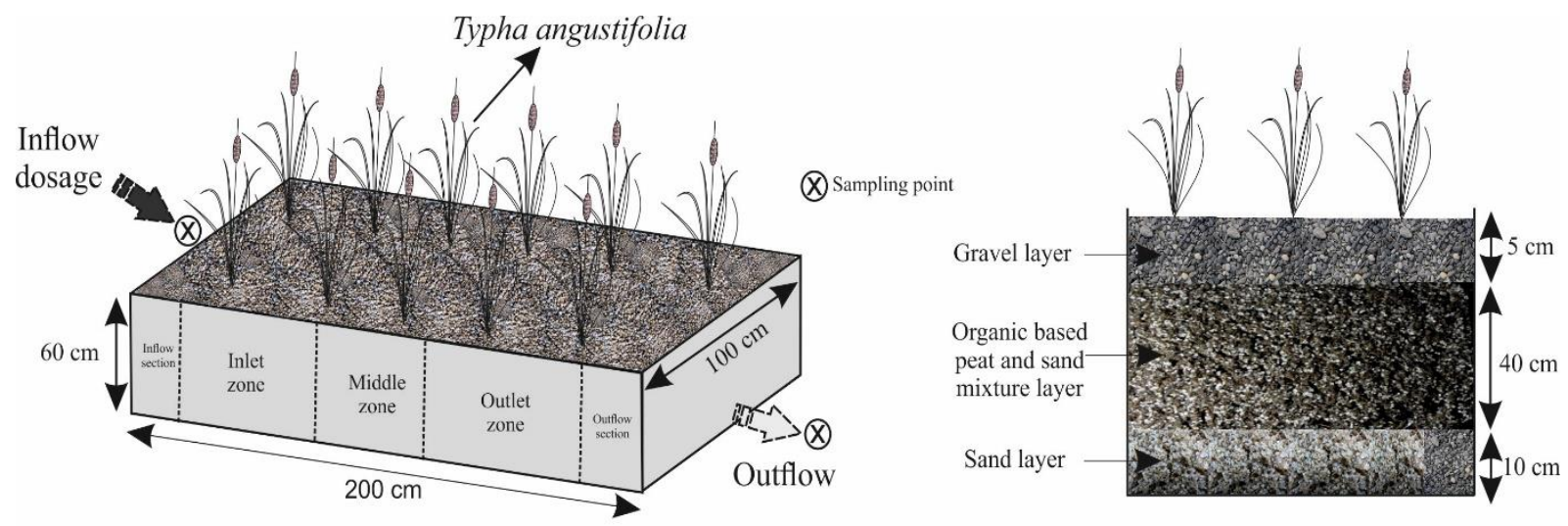

(a)

(b)

Figure 1. Systematic diagram of horizontal flow constructed wetland (HFCW) (a) and filtration material of HFCW (b) in the present experiment

\subsection{Wetland Operation and Mine Effluent Dosage}

After the culture, HFCW was completely established for arsenic bioremediation in the field conditions. The HFCW was filled with the mine effluent obtained from wastewater pool in Kirka Borax mine reserve area, and this mine effluent was pumped into the inflow zone of HFCW. The mine effluent contain arsenic was filled using a pipe, and this feeding period took 1 hour in the present experiment. Every two weeks, HFCW was manually drained through a valve at the bottom of systems and then the system was refilled with fresh mine effluent with various initial arsenic concentrations. The hydraulic retention time of HFCW set to 14 days because this type of flow regimes has a high potential for removal of contamination such as arsenic from wastewater. The arsenic concentration in mine effluent was changed, ranging between $21 \mu \mathrm{g} \mathrm{L}^{-1}$ and $62 \mu \mathrm{g} \mathrm{L}^{-1}$ in the present experiment.

\subsection{Water, Plant, and Media Samples}

\subsubsection{Water samples analysis}

Totally 18 Inflow and 18 outflow water samples (each initial arsenic concentration with triplicate) were taken according to the hydraulic retention time of HFCW during the experiment period, and concurrent with sampling, physicochemical parameter (electrical conductivity, $\mathrm{pH}$, and temperature) were measured with HACH HQ40D multi-parameter meter. Arsenic concentration was analyzed in the laboratory according to the standard methods [7].

\subsubsection{Plant samples analysis}

Typha angustifolia biomass both aboveground and belowground was harvested from the HFCW at the end of the study. After then, T.angustifolia collected from HFCW was separated into roots/rhizome, 
stems, and leaves, and all biomass samples were powdered and digested by $\mathrm{HClO}_{4}: \mathrm{HNO}_{3}$ acid of 1:3 proportions in a microwave digestion unit. The amount of arsenic in T.angustifolia was determined by atomic absorption spectrometer according to Ye et al. [8].

\subsubsection{Media samples analysis}

Media samples from inlet, middle and outlet sections of the HFCW were collected homogenously at the end of the study. The samples were collected from inlet, middle and outlet sections using a 4-cm diameter PVC corer. The amount of arsenic in the media sample was determined by atomic absorption spectrometry method according to Ye et al. [8].

\subsection{Calculation and Statistical Analysis}

Arsenic in the mine effluent loading rate to HFCW was determined according to Debing et al. [11]:

$$
\text { Arsenic loading rate }\left(\mu \mathrm{g} \mathrm{m}^{-2} \mathrm{~d}^{-1}\right)=\left[\left(A_{i} \times V_{i}\right) /(S \times I)\right]
$$

where $\left(A_{i}\right)$ corresponds to arsenic level inflow which is mine effluent flowing into the HFCW, $\left(V_{i}\right)$ refers to standing the mine effluent contain arsenic volume in HFCW, (S) is total unit area of HFCW, (I) is the time between water drainage and refilling.

Arsenic removal performance (\%) of HFCW for mine effluent contains arsenic was calculated as follows:

$$
\text { Arsenic removal performance }(\%)=\left[\left(A_{i} V_{i}-A_{e} V_{e}\right) / A_{i} V_{i}\right] \times 100
$$

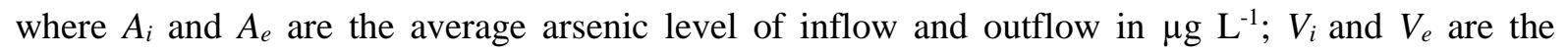
volumes of the outflow and the inflow collected and dosed into HFCW.

Bioconcentration factor (BCF) of T.angustifolia in the HFCW was determined as described by Gao et al. [12]:

$$
B C F=\left(C_{1} / C_{2}\right)
$$

where $\mathrm{C}_{1}$ is arsenic concentration in T.angustifolia organs both in belowground or aboveground parts $(\mathrm{mg} / \mathrm{kg})$ and $\mathrm{C}_{2}$ is arsenic level in the mine effluent $\left(\mu \mathrm{g} \mathrm{L}^{-1}\right)$ at the study period.

Translocation factor (TF) of T.angustifolia in the HFCW was determined as follows:

$$
T F=\left(C_{A} / C_{B}\right)
$$

where $C_{A}$ is arsenic concentration in T.angustifolia tissues in aboveground parts $(\mathrm{mg} / \mathrm{kg}), C_{B}$ is arsenic concentration in the T.angustifolia tissues in belowground parts $(\mathrm{mg} / \mathrm{kg})$

Statistical between the concentrations of arsenic EC, temperature, and $\mathrm{pH}$ in inflow and outflow water samples for HFCW were determined a one-way ANOVA test. Statistical confidence analysis was set at $p<0.05$, and all statistics were implemented using SPSS version 19.0 of the Statistical Software Package. 


\section{RESULTS AND DISCUSSION}

\subsection{Bioremediation Performance of HCFW}

Inflow and outflow arsenic concentration, as well as arsenic removal performance in HFCW system during the whole study period are given in Figure 2. The different arsenic concentrations were dosed to HFCW with fluctuations in the inflow, ranging from $21 \mu \mathrm{g} \mathrm{L}^{-1}$ and $62 \mu \mathrm{g} \mathrm{L}^{-1}$ in the treatment period. As seen in Figure 2, arsenic in outflow were lower than arsenic in inflow, suggesting that HFCW has capable of removing arsenic from the mine effluent $(p<0.05)$. Similar findings have also been reported for arsenic removal by wetland treatment systems which were designed for arsenic bioremediation of various type wastewaters [8, 13-14]. On the contrary, arsenic removal performance of the HFCW was fluctuated in a range of $36-85 \%$ in the experiment period; however no discernible temporal trends were determined for arsenic removal. Specifically, arsenic value in outflow samples of HFCW was stable below $10 \mu \mathrm{g} \mathrm{L}^{-1}$ until the $28^{\text {th }}$ days, and the highest arsenic removal performance was achieved as $60 \%$ at the end of the $28^{\text {th }}$ day. On the other hand, arsenic removal efficiency in HFCW suddenly decreased after $28^{\text {th }}$ day while arsenic concentration in inflow exceeds $60 \mu \mathrm{g} \mathrm{L}^{-1}$ (Figure 2). These results indicated that HFCW components including T.angustifolia and filtration media started to saturate arsenic when inflow arsenic value reached $60 \mu \mathrm{g} \mathrm{L}^{-1}$, and so arsenic bioremediation capacity of the HFCW can decreased because of the overload of bioremediation capacity of the wetland system. Therefore, we suggested that in order to optimize and stabilized arsenic bioremediation performance of the HFCW during the mine effluent bioremediation process, inflow arsenic concentration in mine effluent which is origin of boron mine effluent should not be exceeding $60 \mu \mathrm{g} \mathrm{L}^{-1}$.

Accordingly, arsenic concentration in outflow samples were stably below $10 \mu \mathrm{g} \mathrm{L}^{-1}$ (drinking water safety limit) with an inflow range from 42.3 to 42.1 arsenic $\mu \mathrm{g} \mathrm{L}^{-1}$ during the first 28 days, whereas outflow concentrations were found to be higher than $10 \mu \mathrm{g} \mathrm{L}^{-1}$ when inflow arsenic concentrations exceeded $60 \mu \mathrm{g} \mathrm{L}^{-1}$ (Figure 2). Therefore, it can be hypothesized that the HFCW has a potential for remediating wastewater below drinking water safety limit and further experiment are needed to test this question.

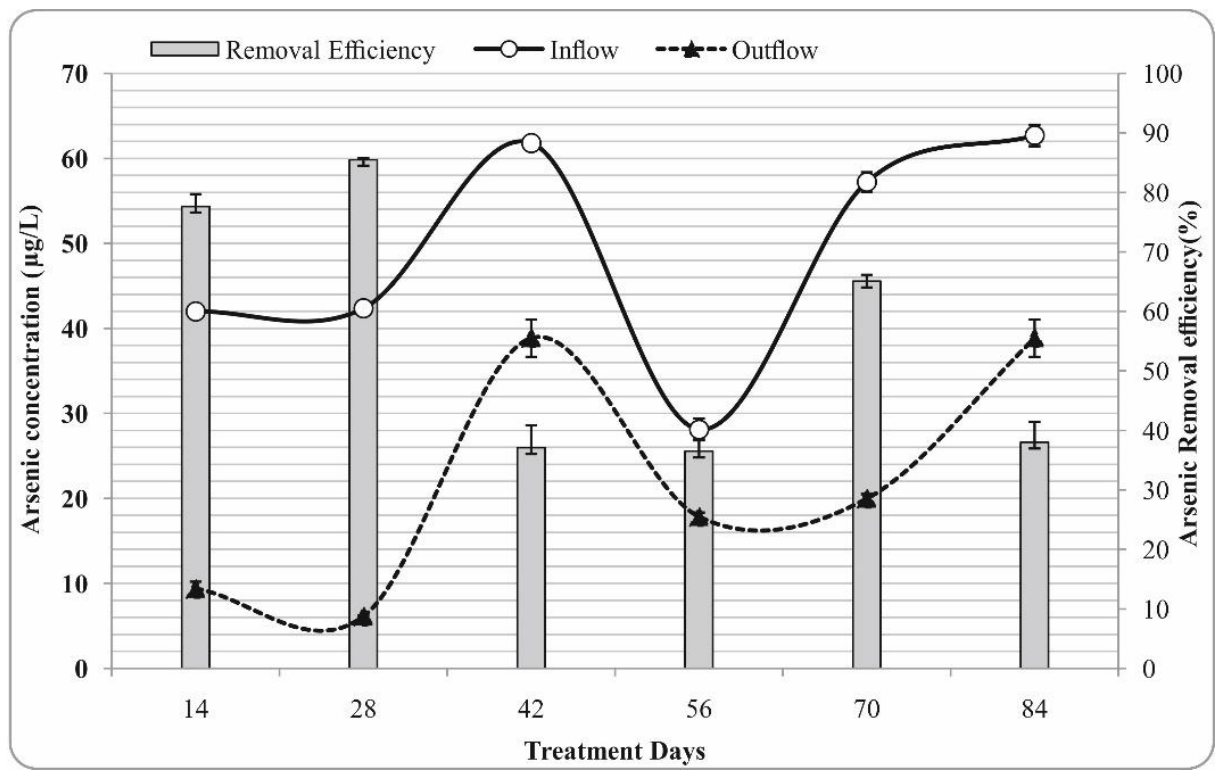

Figure 2. Arsenic concentration in inflow $\left(\mu \mathrm{g} \mathrm{L}^{-1}\right)$, outflow $\left(\mu \mathrm{g} \mathrm{L}^{-1}\right)$ samples, and arsenic removal efficiency $(\%)$ during the experiment period 
The remediating of arsenic from aqueous solution is significantly affected by $\mathrm{pH}$ [8]. In this respect, the $\mathrm{pH}$ of mine effluent also may affect the arsenic treatment efficiency of HFCW by altering wetland matrix, especially with respect to arsenic in HFCW. For example, Limaza et al. [8], at near-neutral to acidic $\mathrm{pH}$, availability of arsenic in wetland matrix increases, and so the adsorption of arsenic by wetland components including media and plant increases at acidic $\mathrm{pH}$ value. As shown in Figure $3 \mathrm{a}$, $\mathrm{pH}$ value emphasized a slight fluctuation during the study period, and $\mathrm{pH}$ values of inflow were lower than outflow samples obtained from HFCW. This result indicates that all of the wetland components adjusted the $\mathrm{pH}$ where the outflow ranged from 8.98 to 7.6, suggesting that wetland matrix was available for arsenic bioaccumulation during the experiment period. Therefore, managers should consider an effect of $\mathrm{pH}$ on arsenic bioremediation while designed a wetland treatment system for arsenic removal from mine effluent.

Electrical conductivity of outflow samples were lower than inflow samples into the HFCW until $70^{\text {th }}$ treatment days. However, no significant difference was found between inflow and outflow samples (Figure $3 b)(p>0.05)$. The results from the present experiment concluded that anionic and cationic ions were not significantly reduced in HFCW during remediation process, indicating that EC bioremediation in wetland matrix is mostly related to physical processes such as sedimentation [17].

There are no discernible temporal trends found for temperature of inflow and outflow samples during the experiment period (Figure 3c). Moreover, no significant difference was found between inflow and outflow water samples $(p>0.05)$. Therefore, it can be concluded that the effect of temperature on arsenic bioremediation process in HFCW can be neglected in the experiment period.

\subsection{Arsenic Content in Plant and Bioaccumulation in HFCW}

Arsenic content in plant growing in HFCW, and bioconcentration factor (BCF) and translocation factor (TF) of T.angustifolia according to location in the wetland system are shown Table 1. As seen in Table 1, arsenic amount in below ground plant parts (roots and rhizomes) were higher than above ground plant parts (leaves and stems) within the entire wetland zone. It was an expected result because higher concentration of arsenic in mine effluent predominantly uptake by belowground parts in HFCW, and so below ground part of T.angustifolia was exposed to more arsenic compared to the above ground plant parts, especially stems. Various researchers also reported similar results that belowground parts of some Typhaceae families have more arsenic content compared to above ground parts for different type of CWs $[15,16]$. Furthermore, T.angustifolia which grows in the outlet zone obtained more arsenic than those towards the inlet and middle zone in HFCW. The results from the present experiment also concluded that an attractive accumulate facility of arsenic acquired within the outlet zone of HFCW and thus T.angustifolia in outlet zone has crucial role in uptake arsenic from waste water such as mine effluent.

The bioconcentration factor (BCF) can defined as the ratio of the total amount of arsenic in the belowground, aboveground or whole plant parts to that growing in mine effluent in terms of the present experiment [17]. It can be seen in Figure 4 that BCF for above ground, below ground, and whole plant parts of T.angustifolia growing in HFCW were higher than those of control in the experiment period. This result supported that arsenic in mine effluent uptake by T.angustifolia in HFCW during the experiment period, and thus T.angustifolia have the potential to be used for arsenic remediation purpose for mine effluent contains arsenic both in Kurka borax mine reserve area and other borax reserves in over the world. Moreover, the BCF of above ground plant parts of T.angustifolia were always higher than that in the belowground (Table 1). The highest BCF was recorded as 7.694 in the plant growing in outlet zone of HFCW, whereas the lowest BCF for arsenic was found as 4.29 for the plant growing in inlet zone. This result concluded that higher concentration of arsenic are dissolved into the outlet zone of HFCW, and so more arsenic is available for T.angustifolia uptake in outlet section. Furthermore, the data calculated in the present experiment also suggested that arsenic accumulated by T.angustifolia was 
largely retained in the belowground parts, and thus belowground parts played a crucial role on the arsenic phytoremediation from mine effluent in the HFCW.

The translocation factor (TF) of T.angustifolia in HFCW according to wetland location is also determined and shown in Table 1. Accordingly, TF value for inlet section was higher than those of the value in middle and outlet section. This phenomenon is seen very often while removing contaminants through in wetland system because more pollutant pass through the wetland unit during the inlet zone compared to the middle and outlet zone, so more sorption sites in inlet zone were available to take up arsenic in the rhizosphere or filtration media of HFCW [14-16]. Nevertheless, remediation strategy associated arsenic behavior in wetland matrix for arsenic removal from mine effluent by HFCW should be investigated carefully by managers while designed own wetland systems.
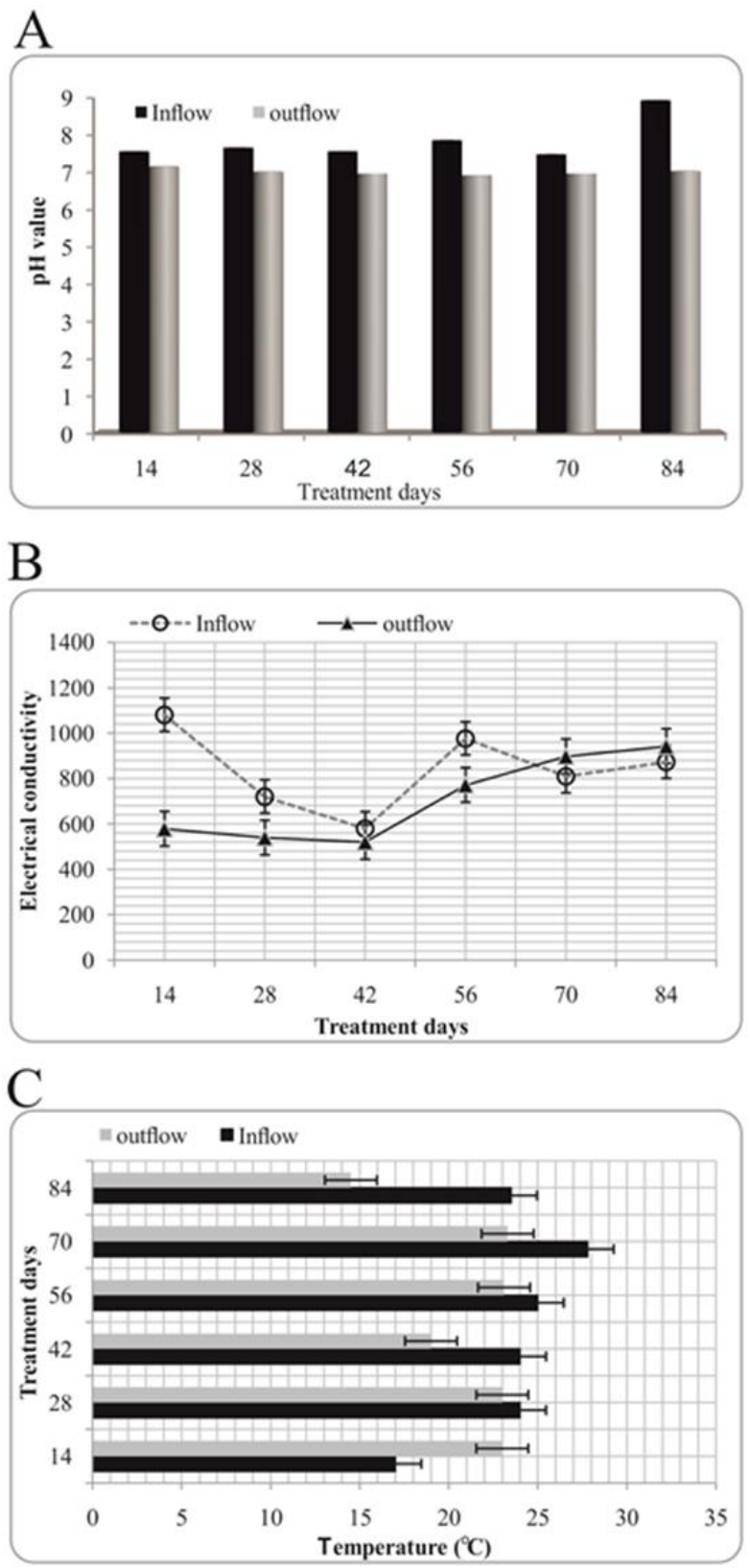

Figure 3. The $\mathrm{pH}$ value (a), EC value (b), and temperature values (c) of the inflow and outflow water samples in the experiment period 


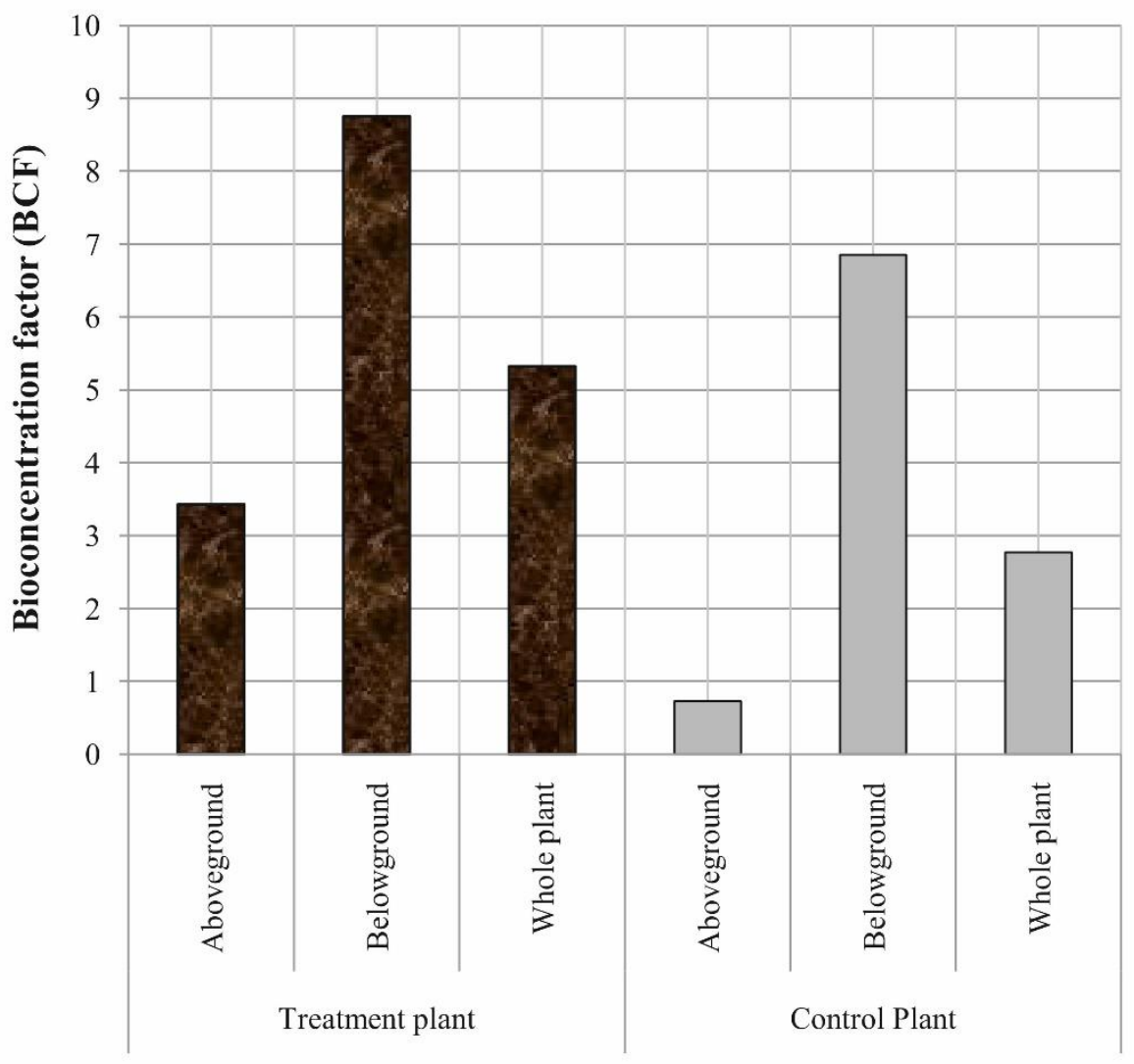

Figure 4. Bioconcentration factor of Typha angustifolia according to plant organs treatment plant and control plant in the experiment period

Table 1. Arsenic concentration in above ground, below ground, and whole plant parts of Typha angustifolia in HFCW, as well as Bioconcentration (BCF) and Translocation factor (TF) of Typha angustifolia in the experiment period. Sing $( \pm)$ corresponds to standard deviation

\begin{tabular}{|l|l|l|l|l|l|l|l|l|l|}
\hline & \multicolumn{3}{|c|}{ Inlet Zone } & \multicolumn{3}{c|}{ Middle Zone } & \multicolumn{3}{c|}{ Outlet Zone } \\
\cline { 2 - 9 } & $\begin{array}{l}\text { Above } \\
\text { ground } \\
\text { parts }\end{array}$ & $\begin{array}{l}\text { Below } \\
\text { ground } \\
\text { parts }\end{array}$ & $\begin{array}{l}\text { Whole } \\
\text { plant }\end{array}$ & $\begin{array}{l}\text { Above } \\
\text { ground } \\
\text { parts }\end{array}$ & $\begin{array}{l}\text { Below } \\
\text { ground } \\
\text { parts }\end{array}$ & $\begin{array}{l}\text { Whole } \\
\text { plant }\end{array}$ & $\begin{array}{l}\text { Above } \\
\text { ground } \\
\text { parts }\end{array}$ & $\begin{array}{l}\text { Below } \\
\text { ground } \\
\text { parts }\end{array}$ & $\begin{array}{l}\text { Whole } \\
\text { plant }\end{array}$ \\
\hline $\begin{array}{l}\text { Arsenic } \\
\text { concentrations } \\
(\mu \mathrm{g} / \mathrm{kg})\end{array}$ & $1076 \pm 874$ & $1640 \pm 945$ & $1264 \pm 912$ & $423.2 \pm 391$ & $1402 \pm 1438$ & $1042 \pm 1204$ & $1113 \pm 1654$ & $3810 \pm 5041$ & $2264 \pm 3412$ \\
\hline $\begin{array}{l}\text { Bioconcentration } \\
\text { factor }\end{array}$ & 3.65 & 5.57 & 4.29 & 1.438 & 4.765 & 3.541 & 3.784 & 12.94 & 7.694 \\
\hline $\begin{array}{l}\text { Translocation } \\
\text { factor }\end{array}$ & - & - & 0.6565 & - & - & 0.3018 & - & - & 0.2924 \\
\hline
\end{tabular}




\subsection{Arsenic Retention in Filtration Media of HFCW}

The concentration of arsenic which are retained in the wetland zones at the end of the study, are given in Figure 5. The results concluded that relatively high level of arsenic retained in the media of HFCW during the experiment period. Moreover, it can be indicated that preparing mixture of organic based peat and sand as a media in wetland matrix has potential to retain arsenic from mine effluent. The results also emphasized that sorption of arsenic in filtration media can be the key mechanism for remediating of arsenic from mine effluent, suggesting that the main arsenic removal pathway in wetland matrix is filtration media storage. Various researchers also found similar results associated with the main removal mechanism of arsenic in wetland matrix [8-9]. In addition, it can be seen in Figure 4 that total arsenic concentrations in HFCW disposed to increase towards the outlet, suggesting that several sorption sites have been taken up arsenic in the outlet zone of HFCW. Thus, further studies should be considering to different parameters such as compaction of filtration media, $\mathrm{pH}$, porosity, particle size while remediating arsenic from mine effluent.

The results come from the present experiment showed that a wetland treatment system could be one of the emerging methods to be evaluated and designed by countries with natural borax reserves to prevent mine effluent pollution in terms of the arsenic. By playing on the evaluated design parameter of wetland systems, their combination of filtration materials, and composition of plants and microorganism could be focused on a crucial goal associated with other type of mine pollutants. In this respect, more investigations addressed the issues for optimize wetland treatment system design and in particular more consideration should be given to present the potential pitfalls of this treatment system.

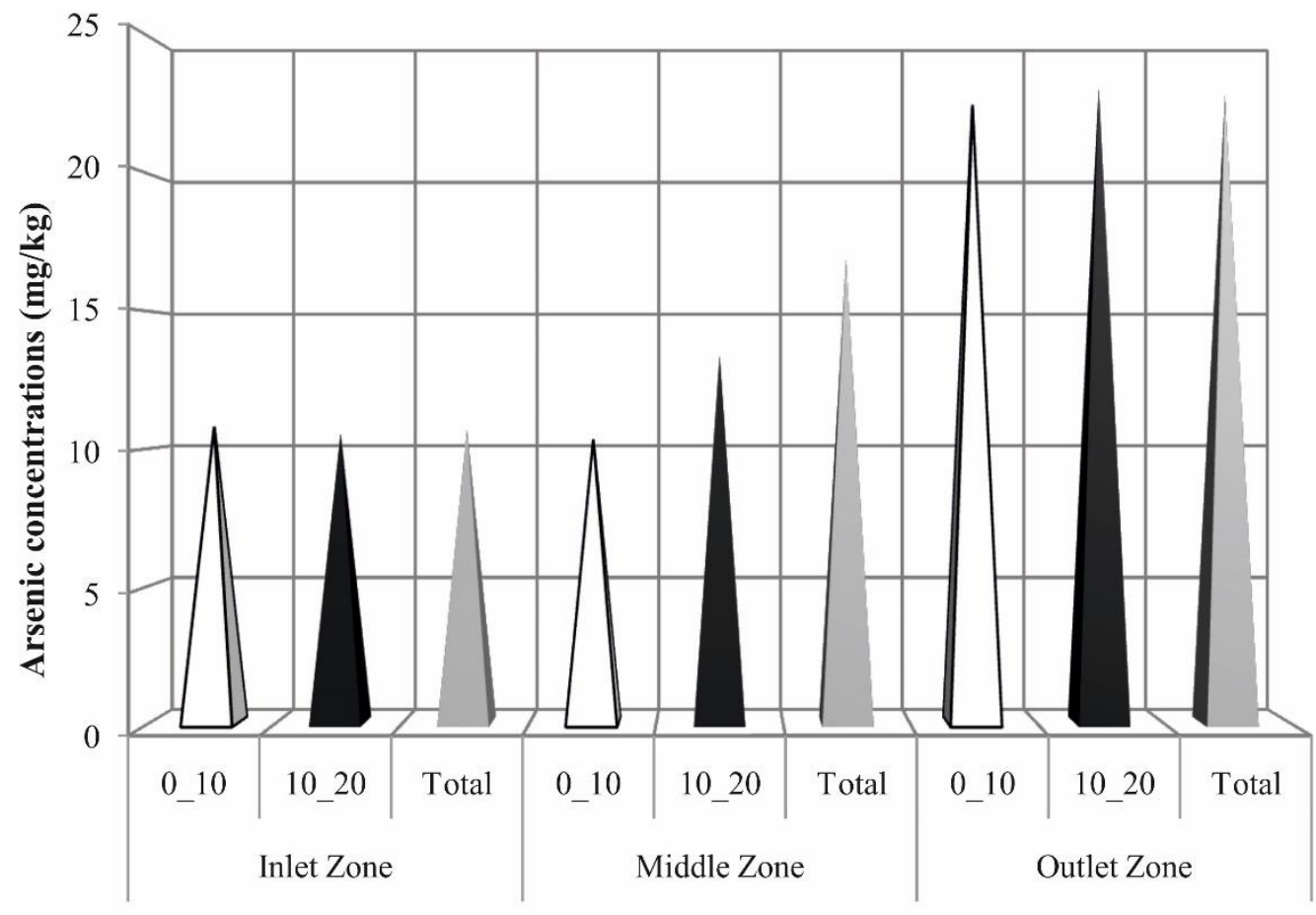

Figure 5. Average arsenic concentration $(\mu \mathrm{g} / \mathrm{kg}$ ) in filtration media according to wetland zone during the experiment period 


\section{CONCLUSIONS}

Arsenic contamination in natural environment can defined as a worldwide problem, and thus attractive applications are necessary to remediate arsenic. The present results concluded that arsenic level in mine effluent effectively reduced through HFCW in experiment period. In this respect, arsenic treatment efficiency was achieved between $36 \%$ and $85 \%$ during the study period. Moreover, arsenic level in outflow samples were stably below $10 \mu \mathrm{g} \mathrm{L}^{-1}$ (drinking water safety limit) with an inflow range from 42.3 to 42.1 arsenic $\mu \mathrm{g} \mathrm{L}^{-1}$ during the first 28 days, suggesting that HFCW has a potential for remediating wastewater below drinking water safety limit. Moreover, the results indicated that the amount of arsenic in the belowground parts of the T.angustifolia were higher than that in the aboveground plant parts. Hence, belowground parts of T.angustifolia have a crucial role in accumulating arsenic from mine effluent. Results from the present experiment also showed that relatively high level of arsenic retained in the filtration media of HFCW during the experiment period, indicating that filtration media which was used in HFCW has potential to filter arsenic.

\section{REFERENCES}

[1] Berg M., Stengel C., Trang P.T.K., Viet P.H., Sampson M.L., Leng M., S. Samreth, Fredericks D., Magnitude of arsenic pollution in the Mekong and Red River Deltas-Cambodia and Vietnam, Science of the Total Environment, 2007; 372: 413-425.

[2] Habuda-Stanić M., Kuleš M., Kalajdžić B., Romić Ž., Quality of groundwater in eastern Croatia. The problem of arsenic pollution, Desalination, 2007; 210: 157-162.

[3] Garelick H., Jones H., Dybowska A., Valsami-Jones E., Arsenic pollution sources, in: Reviews of Environmental Contamination, 2009; 197: 17-60.

[4] Williams M., Arsenic in mine waters: an international study, Environmental Geology, 2001; 40: 267-278.

[5] Türker O.C., Böcük H., Yakar A., The phytoremediation ability of a polyculture constructed wetland to treat boron from mine effluent, Journal of hazardous materials, 2013; 252: 132-141.

[6] Türker O.C., Türe C., Böcük H., Yakar A., Constructed wetlands as green tools for management of boron mine wastewater, International journal of phytoremediation, 2014; 16: 537-553.

[7] Böcük H., Yakar A., Türker O.C., Assessment of Lemna gibba L.(duckweed) as a potential ecological indicator for contaminated aquatic ecosystem by boron mine effluent, Ecol Indic, 2013; 29: 538-548.

[8] Ye Z., Lin Z.-Q., Whiting S., De Souza M., Terry N., Possible use of constructed wetland to remove selenocyanate, arsenic, and boron from electric utility wastewater, Chemosphere, 2003; 52:1571-1579.

[9] Lizama K., Fletcher T.D., Sun G., Removal processes for arsenic in constructed wetlands, Chemosphere, 2011; 84: 1032-1043.

[10] Lyubenova L., Pongrac P., Vogel-Mikuš K., Mezek G.K., Vavpetič P., Grlj N., Regvar M., Pelicon P., Schröder P., The fate of arsenic, cadmium and lead in Typha latifolia: a case study on the applicability of micro-PIXE in plant ionomics, Journal of hazardous materials, 2013; 248: 371-378. 
[11] Debing J., Lianbi Z., Xiaosong Y., Jianming H., Mengbin Z., Yuzhong W., COD, TN and TP removal of Typha wetland vegetation of different structures, Polish J. Environ. Stud, 2009; 18: 183190.

[12] Gao J., Zhang J., Ma N., Wang W., Ma C., Zhang R., Cadmium removal capability and growth characteristics of Iris sibirica in subsurface vertical flow constructed wetlands, Ecological Engineering, 2015; 84: 443-450.

[13] Marchand L., Mench M., Jacob D., Otte M., Metal and metalloid removal in constructed wetlands, with emphasis on the importance of plants and standardized measurements: a review, Environmental pollution, 2010; 158: 3447-3461.

[14] Singhakant C., Koottatep T., Satayavivad J., Enhanced arsenic removals through plant interactions in subsurface-flow constructed wetlands, Journal of Environmental Science and Health Part A, 2009; 44: 163-169.

[15] Goulet R.R., Pick F.R., The effects of cattails (Typha latifolia L.) on concentrations and partitioning of metals in surficial sediments of surface-flow constructed wetlands, Water, Air, and Soil Pollution, 2001; 132: 275-291.

[16] Arroyo P., Ansola G., de Miera L.E.S., Effects of substrate, vegetation and flow on arsenic and zinc removal efficiency and microbial diversity in constructed wetlands, Ecological engineering, 2013; 51: 95-103.

[17] Türker O.C., Türe C., Böcük H., Yakar A., Phyto-management of boron mine effluent using native macrophytes in mono-culture and poly-culture constructed wetlands, Ecological Engineering, 2016; 94: 65-74. 